\title{
DEVELOPMENT OF INVESTMENT ACTIVITIES OF ENTERPRISES OF THE OIL AND GAS CHEMICAL COMPLEX
}

Gulnaz M. Galeeva ${ }^{1}$

Elena N. Zagladina ${ }^{2}$

\begin{abstract}
This paper considers the problems and dynamics of investment activities of enterprises in the Russian economy. In the current context oil and gas companies have got in to a challenging situation against the background of their competitiveness in the world market. Balance between supply and demand has been changed in the course of shale revolution in the United States, due to Iran's coming back to the world's oil market and "market share retention" policy being pursued by the countries - OPEC members. The paper specially consider Tatneft, since it plays an important part in the national, economic, political, public and social life of the Republic of Tatarstan. The
\end{abstract} Company's stable operation in strategic raw materials extraction, its budgetary and hard-currency injections warrant progressive and harmonious development of the Republic. The most important factor for the investing activity it the international agreements of cooperation in oil and gas sector.

Keywords: oil production, taxes, investments, education, competition, profitability, oil companies, international agreements.

\section{Introduction}

Having crucial significance for country's economic policy, oil and gas complex requires special measures of financial assistance on the part of the government. The RF Ministry of economy and finance and the Ministry of Energy have developed the excess profits tax from hydrocarbon production (NDD) bill for introduction of new taxation system taking into account the fair field development cost value. Promotion of economic activity in mature fields' development vi a NDD or

\footnotetext{
${ }^{1}$ Kazan Federal University, Institute of International Relations, History and Oriental Studies. Email: g.m.galeeva@mail.ru, Tel.89046696709.

${ }^{2}$ Kazan Federal University, Institute of International Relations, History and Oriental Studies. Email:49enzagladina52@gmail.com, Tel.89033050481.
} 
any other special exemptions of tax on the extraction of commercial resources(NDPI) can cause production decline and greatly enlarge Foreign Direct Investments into mining which must result in growth of budgetary receipts. By the Ministry of Energy estimates, NDD adopting will facilitate the oil production output of 5 billion tons by the year of 2025. Such Russian companies as Gazprom and Lukoil have already approved NDD bill introduction.

\section{Materials and Methods}

It is noteworthy to mention that there may be different ways of cooperation between the government and private investors in oil and gas complex, such cooperation becoming presently extremely topical:

- in the form of budget financing, self-financing;

- in the form of private and public partnership (on the basis of Production Share Agreement (SRP) or International Project Funding);

- in the form of privatization schemes.

One of the vivid examples there of is the oil and gas company "Sakhalin Energy" having signed such agreement with the state in person of the RF
Government and Sakhalin region administration in 1994. Under provisions of Production Share Agreement the RF Government remains to be the owner of oil and gas fields. At the same time, Sakhalin Energy invests its capital into the deposits' exploration and development.

A special taxation procedure is envisaged for "Sakhalin-2" Agreement, where almost all taxes and customs fees are replaced by production sharing. Thus, SakhalinEnergypays $6 \%$ of royalty instead of the VAT, Oil and Gas Production Tax and other payments due since the first day of oil extraction commencement. Corporate income tax is paid at the rate of $32 \%$ and is transferred to the Russian party (a certain amount of product is delivered in the form of natural gas) [2].

At present Sakhalin Energy comprises such companies as Gazprom, (50\% plus one share), concern Shell, Netherlands-Great Britain (27.5\% minus one share), Mitsui Group of Companies, Japan, (12.5\% of shares), Mitsubishi Group of Companies, Japan (10\% of shares) [3].

There is one more effective Production Share Agreement - the Joint Committee of Kharyaga Agreement. 
After the shares have been changed in 2016 when Total turned over $20 \%$ of its participation and operator functions to Zarubezhneft, the list of investors and the shares allocation look like the following: Total, France (20\%); Zarubezhneft, Russia (operator) (40\%); Statoil, Norway (30\%); Nenetskaya Neftyanaya Kompaniya, OJSC(10\%) [4].

It stands to mention that the decrease in earnings of International Projects based on SRP has taken place particularly, in the Russian Federation due to negative changes of pricing environment in the world energy market. It inevitably brought to cutting down the costs of Kharyaga Agreement realization. After all, the budgets of several regions of the Russian Federation hinge on oil and gas revenues, for instance, the budget of Nenets
Autonomous Region by $90 \%$ depends on oil and gas.

In 2016, the Russian Federation signed the following international agreements of cooperation in oil and gas sector (table 1):

1. The Agreement between the RF Government and the Government of the Socialist Republic of Vietnam for maintenance of cooperation in geological survey and oil and gas extraction within the scope of the Joint Venture RUSVIETPETRO, LLC;

2. Agreement between the RF Government and the Government of the Kyrgyz Republic on enhanced cooperation in the sphere of oil and petrochemicals supplies;

3. The Agreement between the RF Government and the Republic of Turkey Government for Turkish Stream gas pipeline project [5].

Table 1. The largest Russian transactions in oil and gas complex [6]

\begin{tabular}{|l|l|l|l|l|}
\hline \multicolumn{1}{|c|}{$\begin{array}{c}\text { Transaction } \\
\text { object }\end{array}$} & \multicolumn{1}{|c|}{ Buyer } & \multicolumn{1}{|c|}{ Seller } & $\begin{array}{c}\text { Share } \\
\text { in } \%\end{array}$ & \multicolumn{1}{|c|}{$\begin{array}{c}\text { Transaction } \\
\text { volume }\end{array}$} \\
\hline Essar Oil Ltd & $\begin{array}{l}\text { Oil Company } \\
\text { Rosneft }\end{array}$ & Essar & $49 \%$ & $\begin{array}{l}2400 \text { million } \\
\text { dollars }\end{array}$ \\
\hline $\begin{array}{l}\text { E. On E\&P } \\
\text { Norge }\end{array}$ & $\begin{array}{l}\text { DEA Deutsche } \\
\text { Erdoel AG }\end{array}$ & E. On & $100 \%$ & $\begin{array}{l}1600 \text { million } \\
\text { dollars }\end{array}$ \\
\hline
\end{tabular}




\begin{tabular}{|c|c|c|c|c|}
\hline Yamal LNG & $\begin{array}{l}\text { Silk Road Fund Co } \\
\text { Ltd }\end{array}$ & NOVATEK & $9.9 \%$ & $\begin{array}{l}\text { 1400million } \\
\text { dollars }\end{array}$ \\
\hline Sibur Holding & $\begin{array}{l}\text { China Petrochemical } \\
\text { Corporation (Sinopec } \\
\text { Group) }\end{array}$ & $\begin{array}{l}\text { Leonid Mikhelson, } \\
\text { Kirill Shamalov, } \\
\text { Gennadi } \\
\text { Timchenko }\end{array}$ & $10 \%$ & $\begin{array}{l}\text { 1340million } \\
\text { dollars }\end{array}$ \\
\hline Vankorneft & $\begin{array}{l}\text { ONGC Videsh } \\
\text { Limited (OVL) }\end{array}$ & $\begin{array}{l}\text { Oil Company } \\
\text { Rosneft }\end{array}$ & $15 \%$ & $\begin{array}{l}\text { 1300million } \\
\text { dollars }\end{array}$ \\
\hline $\begin{array}{l}\text { RosneftOil } \\
\text { Company }\end{array}$ & $\begin{array}{l}\text { Qatar Investment } \\
\text { Authority and } \\
\text { Glencore (QHG } \\
\text { Shares Pte. Ltd) }\end{array}$ & $\begin{array}{l}\text { Oil Company } \\
\text { Rosneft }\end{array}$ & $\begin{array}{l}19.5 \% \\
(50 / 50)\end{array}$ & $\begin{array}{l}10200 \\
\text { million euro } \\
\text { [7] }\end{array}$ \\
\hline Kharyaga SRP & Zarubezhneft & Total & $20 \%$ & $\begin{array}{l}60 \text { million } \\
\text { dollars [8] }\end{array}$ \\
\hline Vankorneft & $\begin{array}{l}\text { Consortium Oil } \\
\text { India, Bharat } \\
\text { PetroResources, } \\
\text { Indian Oil }\end{array}$ & $\begin{array}{l}\text { Oil Company } \\
\text { Rosneft }\end{array}$ & $23.9 \%$ & $\begin{array}{l}2100 \mathrm{mln} \\
\text { dollars [9] }\end{array}$ \\
\hline
\end{tabular}

At present, foreign companies are able to participate in shelf development only as minority partners of state Russian concerns Rosneft and Gazprom. For instance, Rosneft works conjointly with the Italian Company Eni and the Norwegian Stat oil, previously being a part of consortium with the French Company Total for Shtockman's Project development, now being suspended. In 2016 Rosneft possessed 55 licenses for
Russian continental shelf development with hydrocarbon reserves on its territory of about 43 billion tons of crude oil equivalent. Being the largest user of natural resources, the Company is developing shelf projects in the Black Sea at the Abkhazian coast, surveying and producing at Vietnam shelf, at the same time, taking part in the project on Novergian shelf [10]. 


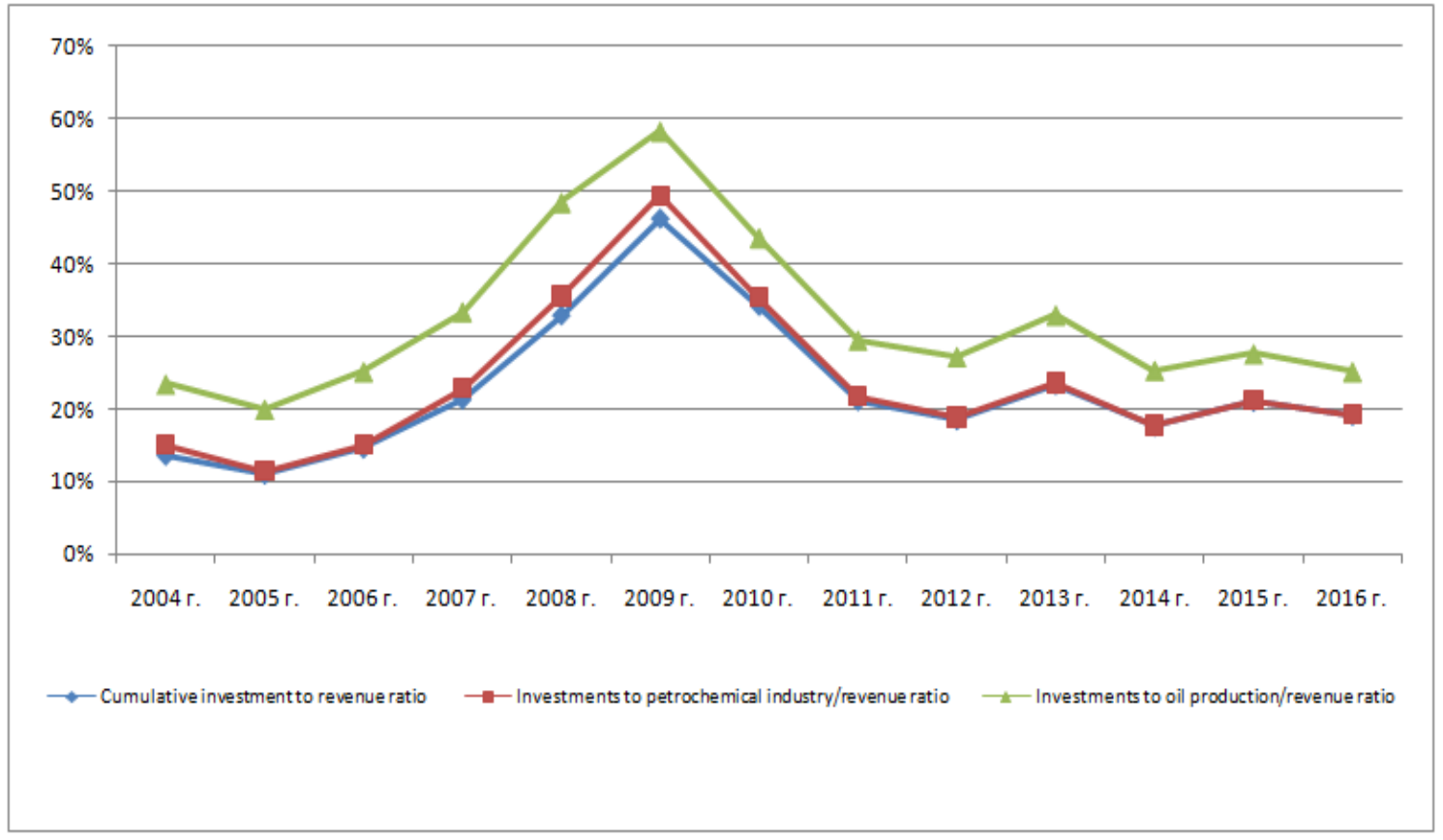

Fig.1 - Dynamics of PAO TATNEFT investment activities in 2004-2016.

It should be noted that if the profit of the enterprise is the main source of investment, taxation imposing a significant impact on the company's investment activity. To consider the dynamics of TATNEFT investment activity let us examine Fig.1.

As is clear from Fig. 1, the company's investments have given a significant growth since 2007 , i.e. since the time when preferential taxation system according to NDPI was brought into force. Dampening of the company's investment activity started from 2009 and continued in 2014/2016. One of the key components of the Company's successful operation lies in a strong support and deliberate attention to the
Republican oil sector on the part of the RT President and its Government.

\section{Results and Discussion}

The global experience shows that the development of gas and oil sector needs a government support for:

- infrastructure development within the scope of gas and petrochemical clusters;

- facilitation of inner demand and export;

- upgrading promotion of obsolescent productive facilities;

- rendering financial assistance to the whole sector; 
- application of measures to eliminate administrative restrictions and barriers;

- enhancing investment attractiveness of oil and gas petrochemical complex by means of tax incentives and financial promotion.

For the purposes of expand oil and gas sector development and attraction of investors therein, it is necessary to develop engineering, transportation and logistics infrastructure. Public and Private Partnership mechanisms are the primary basis for such infrastructure elaboration. An efficient instrument of Public and Private Partnership appears to be project financing, concessionary agreements based on BOO (Build - Own - Operate), BOOT (Build - Own - Operate Transfer) and others schemes, concluded for the infrastructural objects operation within 30 years, as well as governmental co-financing of expenditures for the infrastructure developmentwithin20$50 \%$ from the prime cost.

\section{Summary}

Investment cooperation of India and Russia in hydrocarbon sector is of great significance. In 2015 Rosneft and Essar signed an agreement for 10 years on procurement of $49 \%$ of shares in Essar oil refinery plant in Vadinar and further oil delivery to Essar. Moreover, in2015 OVL and Rosneft signed a contract for procurement of $15 \%$ of share in Vankorneft project. As early as in June, 2016 the Indian Consortium and Rosneft signed the sale and purchase agreement of $23.9 \%$ of shares in Vankor oil field, since the deposit needs new investments to support extraction process in the current context [11].

The share of petrochemical industry sector mounts to $10 \%$ and even more in net sales of the largest oil and gas companies such as Exxon Mobil, British Petroleum, Shell, Chevron-Texaco, Conoco - Philips and a number of others. Since petrochemical industry market appears to be more and more globalized in terms of new technologies spreading, raw materials and sales areas availability, the companies operating in the industry face mutual problems such as legislative regulation, price formation and a reduction in quantity of "a heavier feedstock". Nevertheless, in view of various starting lines and historically developed weak and strong points, the prospects for petrochemical industry progress in the regions are marked far different. 


\section{Conclusions}

At the present stage oil and gas industry in Russia is one of the stimulifor progress and economic development. Even though at present we see the tendency of market liberalization, this economic sector significance induces the government to promote investment cooperation [1].

The investment activity in the Republic is implemented in accordance with the investment program. Tatneft group of companies' cumulative investment in 2015 made 97219 million rubles. The geographical spread of its investors covers the main part of Russian territory, as well as North America, Australia, Europe and Asia. The main principles of the investment activity corporate management policy are as follows: investments in the most effective projects according to optimization results; incentivization of the expected return rate achievement according to each trend of the investment activities; estimation and effectiveness monitoring of all investment projects.

The Company operates and steadily updates the unified investment projects passport data. The Company's Investment Committee functions as a governing centre of the investment programs development and execution monitoring. The current investment activity is carried out by Investments Governance of Tatneft. Such governance is based on standard consideration procedures, assessment and decision making. The given procedures are provided by the Investment Committee conjointly with Tatneft Investment Governance.

Oil and gas sector in our country is one of the most attractive branches for foreign investors due to several reasons: availability of raw material base; comparatively in expensive but highly qualified workforce; availability of advanced production infrastructure in most of the mining areas; relatively low cost of oil and gas field operation; capability of export delivery realization.

\section{Acknowledgements}

The work is performed according to the Russian Government Program of Competitive Growth of Kazan Federal University.

\section{Reference and Literature}

Special aspects of oil and gas industry [Electronic recourse] / «Expocenter». Official site. $\quad-\quad$ URL: 


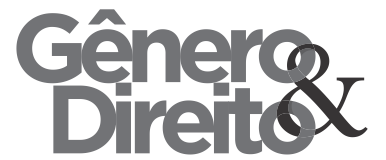

Periódico do Núcleo de Estudos e Pesquisas sobre Gênero e Direito

Centro de Ciências Jurídicas - Universidade Federal da Paraíba V. 8 - $\mathrm{N}^{\circ} 04$ - Ano 2019 - Special Edition ISSN | 2179-7137 | http://periodicos.ufpb.br/ojs2/index.php/ged/index http://www.neftegaz-

expo.ru/ru/articles/osobennosti-

neftegazovoj-otrasli/ (reference date 21.04.2017).

Production Share Agreement [Electronic recourse] / Sakhalin Energy- Official site.

URL:

http://www.sakhalinenergy.ru/ru/compa ny/production_sharing.wbp (reference date 23.04.2017).

Background Information [Electronic recourse]/ Sakhalin Energy- Official site.

URL:

http://www.sakhalinenergy.ru/ru/compa ny/overview.wbp (reference date23.04.2017).

Costson Kharyaga SRP for 2016 cutby $20 \%$, up to $\$ 318$ billion [Electronic recourse] / Online media RIA Novosti Russian Information Agency - Official site.URL: https://ria.ru/economy/20160428/14224 61375.html (reference date 23.04.2017). International documents signed in 2016 [Electronic recourse] /The RF Ministry of Energy. - Official site. - URL: http://minenergo.gov.ru/node/7553 (reference date 23.04.2017).
Bulletin "Mergers and Acquisitions Market" Information Agency AK\&M. 2015. - No 204. - p. 89.

Totals of 2016: Oil transactions expected, mysterious, sensational, [Electronic recourse] / Interfax. Official site. - $\quad$ URL: http://www.interfax.ru/business/543725 (reference date: 30.04 .2017 ).

Zarubezhneftwillpay $\$ 60 \mathrm{mln}$ to Total for transfer of $20 \%$ in Kharyaga SRP [Electronic recourse] / Finanz.ru. Official site. $\quad-\quad$ URL: http://www.finanz.ru/novosti/aktsii/zaru bezhneft-zaplatit-Total-okolo-\$60-mlnza-peredachu-20percent-vkharyaginskom-srp-1001336666 (reference date: 30.04.2017)

Vankorf lows to India again [Electronic recourse] / Commersant- Official site. URL:

https://www.kommersant.ru/doc/301707 5 (reference date: 30.04 .2017 ).

Shelf Projects [Electronic recourse]/ Rosneft. - Official site. - URL: https://www.rosneft.ru/business/Upstrea $\mathrm{m} /$ offshore/ (date of reference: 26.04.2017). 
India and Russia: Special partnership continues [Electronic recourse] / Inosmi

- Russia today. - Official site. - URL: http://inosmi.ru/politic/20160826/23764 4905.html, free. (date of reference28.04.2017).

Galeeva, G.M., Fazlieva, E.P., Mingazova, R.K., Zinurova, R.I. Innovation as a part of strategic management and enterprise competitiveness of petrochemical cluster // Social Sciences and Interdisciplinary Behavior - Proceedings of the 4th International Congress on Interdisciplinary Behavior and Social Science, ICIBSOS 2015. c. 213-216 